\title{
Human, Earth, and Future
}

\section{Production of Biodiesel from a Novel Combination of Raphia Africana Kernel Oil and Turtle Shell (Centrochelys Sulcata) Heterogenous Catalyst}

\author{
Henry Oghenero Orugba ${ }^{1} \mathbb{\oplus}$, Kigho Moses Oghenejoboh ${ }^{1 *}{ }^{*}$, Ufuoma Modupe Oghenejoboh ${ }^{2}$, \\ Onogwarite E. Ohimor ${ }^{3}$ \\ ${ }^{1}$ Department of Chemical and Petroleum Engineering, Delta State University Abraka, Oleh Campus,P.M.B 22, Oleh, Nigeria \\ ${ }^{2}$ Department of Chemistry, University of Ibadan, P.O. Box 22133, Ibadan, Nigeria \\ ${ }^{3}$ Department of Chemical Engineering, College of Engineering and Technology, Federal University of Petroleum Resources, \\ Ugbomoro- Effururn, Warri, Nigeria
}

Received 13 June 2021; Revised 15 August 2021; Accepted 21 August 2021; Published 01 September 2021

\begin{abstract}
This work investigated the viability of a non-edible oil obtained from raphia africana in the production of biodiesel using a novel heterogeneous catalyst derived from turtle shells (Centrochelys sulcata). The study also proposed the use of acetone as a co-solvent to enhance the solubility of the reacting mixtures. The turtle shells were calcined at $900^{\circ} \mathrm{C}$ for 3 hours, impregnated with $\mathrm{KOH}$ to improve their activity, and then supported with activated carbon produced from cassava peels to increase their surface area. The influences of $\mathrm{KOH}$ concentration, catalyst loading, catalyst/carbon mix ratio, and the concentration of acetone/methanol on the yield of biodiesel were investigated. The results obtained revealed that a maximum biodiesel yield of $93 \%$ was obtained from the bio-oil at a $\mathrm{KOH}$ concentration of $30 \%$ (w/w), catalyst loading of $6.5 \%$, a solvent/methanol ratio of 0.4 and a catalyst/carbon weight ratio of 1.25 . The activated carbon supported turtle shell catalyst has been found to possess very high catalytic activity, converting bio-oil with a high saturated fatty acid content to biodiesel with excellent fuel properties and a low saturated fatty acid profile.
\end{abstract}

Keywords: Biodiesel; Turtle Shells; Raphia Africana; Calcination; Catalyst, Fatty Acid.

\section{Introduction}

The emission of greenhouse gases from the burning of fossil fuels and their steady depletion coupled with increased industrialization and global population growth is a serious problem that requires immediate attention [1-3]. Other concomitant pollution problems associated with fossil fuels' exploration, processing, and distribution make their substitution inevitable [4]. This has made the consideration of different eco-friendly and renewable sources of energy, such as wind, solar, geothermal, wave, and biofuels, imperative [5-7]. Studies have shown that green or biofuel holds great potential as an alternative to liquid fossil fuel $[8,9]$. Two major bio-based fuels that can potentially replace petroleum-based fuels are bio-ethanol and biodiesel [10-12]. Biodiesel is a good alternative to petroleum-based diesel fuel because of its distinct advantages. Some of these advantages are that it is not hazardous, it has a high flash point, it burns cleanly without sooth, and it is safe because of its low flammability index and high lubricity [13]. Despite its

\footnotetext{
* Corresponding author: kmoghene@yahoo.com

> This is an open access article under the CC-BY license (https://creativecommons.org/licenses/by/4.0/).

(C) Authors retain all copyrights.
} 
low flammability index, biodiesel can effectively be used in internal combustion engines without any engine modification by blending it with a small quantity of petrol, diesel, and or ethanol to improve the flammability index [14-17]. Such a diesel blend is eco-friendly and exhibits better fuel properties such as high cetane number, high flash point, and high oxygen with low carbon dioxide emission [14, 18-21]. For example, Selaimia et al. [22] noted that the cetane number and other fuel parameters of biodiesel produced from waste cooking oil blended with a little petrol diesel show a great improvement over that of petrol diesel.

Biodiesel is obtained from some renewable biological materials like vegetable oils, animal fats, and microbial (e.g. microalgae) oils, mainly by reaction with short-chain alcohols in a process known as transesterification [23, 24]. Generally, transesterification reactions are carried out using acidic or basic homogeneous catalysts, which makes the reaction very slow, hence the low product yield. Biodiesel yield is also a function of the free fatty acid (FFA) content of the oil used. Due to their high FFA, edible vegetable oils, animal fats, palm oil, and palm kernel oil (PKO) have been found to give a high yield of biodiesel when transesterified using basic catalysts [15, 22, 23, 25, 26]. However, as a result of its serious threat to food security, the utilization of edible oils for biodiesel synthesis is not encouraged [27, 28].

The choice of catalysts in the transesterification reaction is of utmost importance as it determines the reaction rate as well as the yield of biodiesel. The biodiesel yield depends greatly on the FFA of the oil used. The alkali-based homogeneous catalysts most favoured for the transesterification reaction result in an undesired saponification reaction if the FFA content of the oil used is greater than $1 \% \mathrm{w} / \mathrm{w}$ and this is difficult to separate from the reaction products, leading to a low yield of biodiesel [24, 29]. Acid-based catalysts have been seen as alternative alkali-based catalysts since they do not form soap or other by-products. However, the reactions are extremely slow and corrode the reactors [30]. To mitigate the combined shortcomings of both the alkali-based and acid-base homogeneous catalysts, a heterogeneous catalyst has been proposed and research work has been going on to authenticate its seeming advantages. Since heterogeneous catalysts are solid catalysts, they do not react with the FFA of the oil used in the reaction, thereby improving the catalytic properties for both esterification and transesterification reactions [29, 31, 32]. Other distinct advantages of heterogeneous over the homogeneous catalyst are its ease of recoverability and regeneration after use as well as its ability to increase its activities over a wide range of feedstock during esterification and transesterification reactions due its turning ability to create acidic-basicity characteristics because of its porosity and surface area that does not require pre-treatment for FFA reduction $[33,34]$.

Various studies have shown that homogeneous catalysts developed from different materials like egg shells, crab shells, mollusk shells, and animal bones give a good yield of biodiesel [35-37]. Another excellent precursor of heterogeneous catalysts is calcium oxide, derived from marine shells and animal bones during heat activation [31]. However, this thermal activation process is expensive due to the high temperature required to attain the activation level. Earth metals have also proved to be an effective heterogeneous catalyst for biodiesel production from oil seed. For example, De Sousa et al. [38] carried out a study on the application of calcium oxide (CaO) obtained from calcined eggshells as a catalyst and obtained a $96 \%$ conversion of soybean oil to biodiesel at a moderate temperature. On the other hand, Putra [39] reported a $71 \%$ conversion of used cooking oil to biodiesel using pure $\mathrm{CaO}$ and a $91 \%$ conversion with $\mathrm{CaO}$ doped with silicon dioxide $\left(\mathrm{SiO}_{2}\right)$. Other workers also recorded excellent results using nonconventional heterogeneous catalysts. Sulaiman \& Amin [40] studied the kinetics of waste cooking oil in the production of biodiesel using fish bones and obtained a significant biodiesel yield. Ali et al. [41] obtained an 84\% biodiesel yield from the transesterification of waste cooking oil using calcined goat bones as catalysts. One major problem associated with the use of heterogeneous catalysts is their low surface area, but this can usually be increased by supporting them with compounds such as activated carbon or nanotubes or impregnating them with base solution [31, 32, 42, 43] However, activated carbon is preferred as a heterogeneous catalyst supporter because of its large surface area and its ease of separation from the product [42, 44]. Hadiyanto et al., [32] obtained a 95\% biodiesel yield using a heterogeneous synthesized from green mussel shells calcined at $900^{\circ} \mathrm{C}$ for 3 hours, supported with activated carbon and impregnated in concentrated sodium hydroxide. Buasri et al. [42] obtained a $98 \%$ yield using calcium oxide calcined at $500^{\circ} \mathrm{C}$ for $5 \mathrm{hrs}$ supported with activated carbon and impregnated in potassium hydroxide. Zhang \& Meng [44] obtained a 95\% biodiesel yield using an activated carbon-supported heterogeneous catalyst derived from waste scallop shells calcined at $1000^{\circ} \mathrm{C}$ for 3 hours and impregnated in potassium hydroxide.

In the present study biodiesel is produced from raffia oil; a non-edible and poisonous oil with no known economic value using turtle shell; a non-convectional heterogeneous catalyst impregnated with potassium hydroxide (KOH). The combined use of raphia oil and impregnated tuttle shell are novel initiative since to the best of our knowledge, no known study on this had been reported anywhere.

\section{Materials and Method}

\subsection{Materials}

The Raphia africana oil used in this work was extracted from raffia palm fruits obtained from Angalabiri community of Bayelsa State in the Niger Delta Area of Nigeria. Methanol, hexane, acetone and potassium hydroxide were obtained in analytical grade from Pyrex chemical stores in Benin City, Nigeria while the turtle shells were locally 
sourced from fish farmers in Angalabiri and adjoining fishing communities. Activated carbon used as catalyst support was prepared locally from cassava peels.

\subsection{Experimental Procedure}

\subsubsection{Preparation and Characterization of Heterogeneous Catalyst from Turtle Shells}

The obtained turtle shells were washed in warm water several times in order to remove dirt and oily materials and dried for $3 \mathrm{hrs}$ in a dryer (DGH-9053) at $120^{\circ} \mathrm{C}$ to remove moisture. The shells were then subjected to heat activation at $900^{\circ} \mathrm{C}$ for $3 \mathrm{hr}$. The choice of $900^{\circ} \mathrm{C}$ calcinations temperature was based on the fact that all carbon dioxide desorption on the turtle shell may have been completely eliminated at this temperature creating active sites for calcium oxide $(\mathrm{CaO})$ which favours transesterification reaction $[45,46]$. After the calcination step, the calcined sample was properly crushed using a mortar pestle and sieved to 80 mesh size. In order to study the influence of activated carbon support on the catalyst surface area, the catalyst was mixed with activated carbon prepared from cassava peels following the method of Oghenejoboh et al. (2016) [50]. The catalyst was then mixed with varying ratios of the prepared activated carbon on w/w basis before impregnating it with 15, 20, 25, 30, 35 and 40\% (w/w) solutions of potassium hydroxide for $12 \mathrm{hrs}$ to improve the catalyst activity [32,41]. The prepared catalysts was filtered using a filter paper, dried in an oven at $110^{\circ} \mathrm{C}$ for $4 \mathrm{hrs}$ and stored in a container containing silica gel to prevent it from absorbing atmospheric moisture from the surrounding. The catalyst was then subjected to FTIR analysis in order to study its morphology at the calcined conditions. The Buck scientific M530 USA FTIR equipped with a detector and beam splitter was used for the analysis. The spectra were obtained using the Gram A1 software. During measurement, FTIR spectrum was obtained at frequency regions of $4,000-600 \mathrm{~cm}^{-1}$ with resolution of $4 \mathrm{~cm}^{-1}$ from the accumulation of 32 scans.

\subsubsection{Extraction and Characterisation of Raphia Seed Oil}

Raphia seeds were detached from raphia palm bunches collected from the swampy area of Angalabiri in Bayelsa State of Nigeria. The seeds were dried for two weeks before cracking them open to obtain the oil-bearing kernels. The kernels were thoroughly washed and subjected to size reduction by crushing using a mortar and pestle. The solvent extraction method using a soxhlet and analytical grade hexane as solvent was then used to extract the oil from the crushed kernels. The Buck M910 Scientific gas chromatography coupled to FID with detector (USA) having column dimensions $100 \mathrm{~m} \times 0.25 \mathrm{~mm}$ ID $\times 0.20 \mu \mathrm{m}$ film thickness was used to determine the constituents of the produced biooil and the resultant biodiesel. The experimental conditions were as follows: inlet temperature of column was $60^{\circ} \mathrm{C}$ for $1 \mathrm{~min}$, then at a gradient of $15^{\circ} \mathrm{C} / \mathrm{min}$ up to $165^{\circ} \mathrm{C}$ for $20 \mathrm{~min}$, a gradient of $2{ }^{\circ} \mathrm{C} / \mathrm{min}$ up to $225^{\circ} \mathrm{C}$. The injector volume was $1 \mu \mathrm{L}$ while the injector/detector temperature was $250^{\circ} \mathrm{C}$. Carrier gas was helium and its flowrate was $0.8 \mathrm{~mL} / \mathrm{min}$. The sample's contents were identified by comparing their retention time against standards.

\subsubsection{Transesterification Experiment}

The transesterification reactions were performed in a $250 \mathrm{ml}$ conical flask with pre-determined small volume of acetone added as co-solvent. The choice of acetone over other co-solvents such as diethyl ether (DEE) and dichlorobenzene $(\mathrm{CBN})$ as co-solvent systems was based on its distinct advantages as reported by Alhassan et al. [47]. Based on oil weight, a predetermined mass of catalyst was measured and added into a conical flask containing a predetermined mass of methanol and stirred at $60^{\circ} \mathrm{C}$ for $30 \mathrm{~min}$. This was to allow proper dispersion of the catalyst before adding the oil. A predetermined mass of oil preheated to $60^{\circ} \mathrm{C}$ was measured and poured into the catalyst/methanol mixture and this was quickly followed by adding the acetone co-solvent (in basis of the methanol volume). It has been widely reported that increasing the reaction temperature, increasing stirring speed and increasing methanol/oil ratio increase biodiesel yield, however, variation of these three variables were not considered in this study. In all the experiments, reaction temperature of $65^{\circ} \mathrm{C}$, stirring speed of 300rpm [40], methanol/oil ratio of 1:2 $(\mathrm{w} / \mathrm{w})$ and reaction time of $3 \mathrm{hr}$ [32] were used except in the reactions to investigate influence of the co-solvent where time was 30 minutes. The influences of four major variables- Catalyst/carbon ratio (w/w), catalyst weight per weight of oil, concentration of potassium hydroxide and co-solvent/methanol ratio (v/v) were considered in this research. Catalyst/carbon ratio was varied between 0.5 and $1.75(\mathrm{w} / \mathrm{w})$; catalyst concentration $2-10 \mathrm{wt} \%$, KOH concentration of $15-40 \%(\mathrm{w} / \mathrm{w})$ and co-solvent/oil ratio of $0-0.8(\mathrm{v} / \mathrm{v})$. At the end of a reaction, the reaction mixture was poured into a separating funnel through a filter paper in order to separate the catalyst. After 6 hours, the methyl ester phase was carefully separated, washed with warm distilled water at $45^{\circ} \mathrm{C}$ in order to remove impurities (excess glycerol and methanol), dried for $24 \mathrm{hr}$ at room temperature. The percentage volume yield of the biodiesel was calculated according to Equation 1.

$\%$ Biodiesel yield $=\frac{\text { vol of FAME produced-vol of acetone cosolvent }}{\text { vol of oil used }} \times 100$

\section{Results and Discussion}

\subsection{Catalyst Characterization}

The prepared turtle shell catalyst was characterized using the FTIR analysis to determine its morphology. Figure 1 show the spectra of turtle shell catalyst calcined at a temperature of $900^{\circ} \mathrm{C}$ for a period of $3 \mathrm{hr}$. 


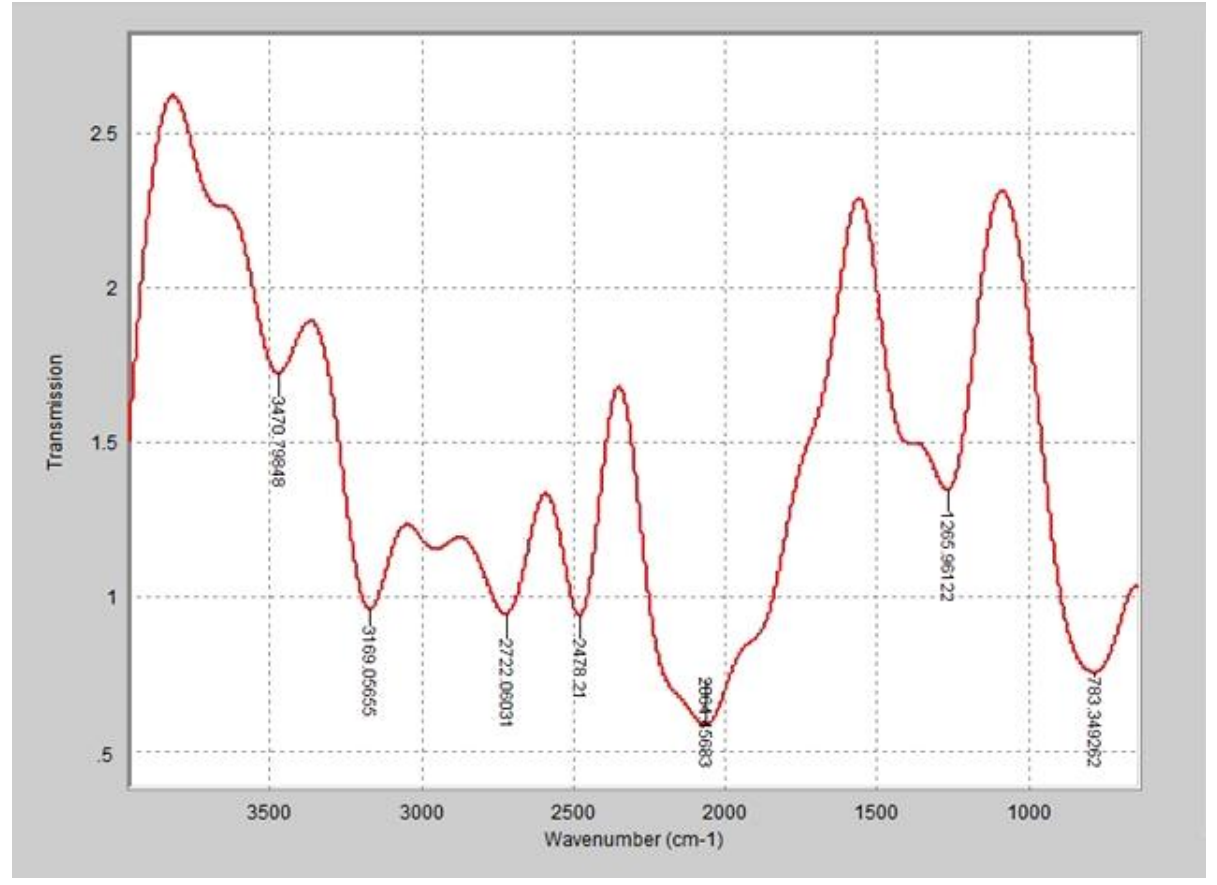

Figure 1. FTIR spectrum of the shell calcined at $900^{\circ} \mathrm{C}$ for $3 \mathrm{hr}$

As shown in Figure 1, the FTIR spectrum of the turtle shell calcined at $900^{\circ} \mathrm{C}$ for 3 hours produces sharp bands at $3470,3169,2722,2478,2064,1265$ and $783 \mathrm{~cm}^{-1}$. Most of these bands correspond to the production of calcium containing compounds with terminal amines. For example, the peak at the $3470 \mathrm{~cm}^{-1}$ produces $\mathrm{N}-\mathrm{H}$ stretch; a secondary amine group. This may be as a result of the oily nature of turtle shell; however, this is temporary as indicated by the symmetric $\mathrm{CH}_{3}$ and $\mathrm{CH}_{2}$ stretches at the 2722 and $2478 \mathrm{~cm}^{-1}$ peak respectively culminating into a bending (rocking) motion associated with a long chain band of four or more $\mathrm{CH}_{2}$ groups. The wide and strong band produced at the $2064 \mathrm{~cm}^{-1}$ wavelength band indicates the appearance of the $\mathrm{Ca}-\mathrm{O}$ bond which shows the complete elimination of carbon dioxide from the turtle shell, thereby producing the required $\mathrm{CaO}$ active site for effective transesterification reaction. This finding is in agreement with that of Wembabazi et al. [45] and Birla et al. [36], working with eggshells and snail shells calcined at $900^{\circ} \mathrm{C}$ for 3 and 4 hours respectively. Turtle shell calcinations temperature lower than $900^{\circ} \mathrm{C}$ gives incomplete carbonization as shown by the results of Xie et al. [48] who carried out turtle shell carbonization at a temperature of $200-700^{\circ} \mathrm{C}$. The results obtained by these workers may be as a result of the formation of carbonate group $\left(\mathrm{CO}_{3}^{2-}\right)$ represented by asymmetric $\mathrm{C}-\mathrm{O}$ band in the FTIR analysis.

\subsection{Bio-oil and Biodiesel Characterization}

The fatty acid profiles of the oil and the produced biodiesel are presented in the chromatographs shown in Figures 2 and 3 with the results summarized in Tables 1 and 2 respectively.

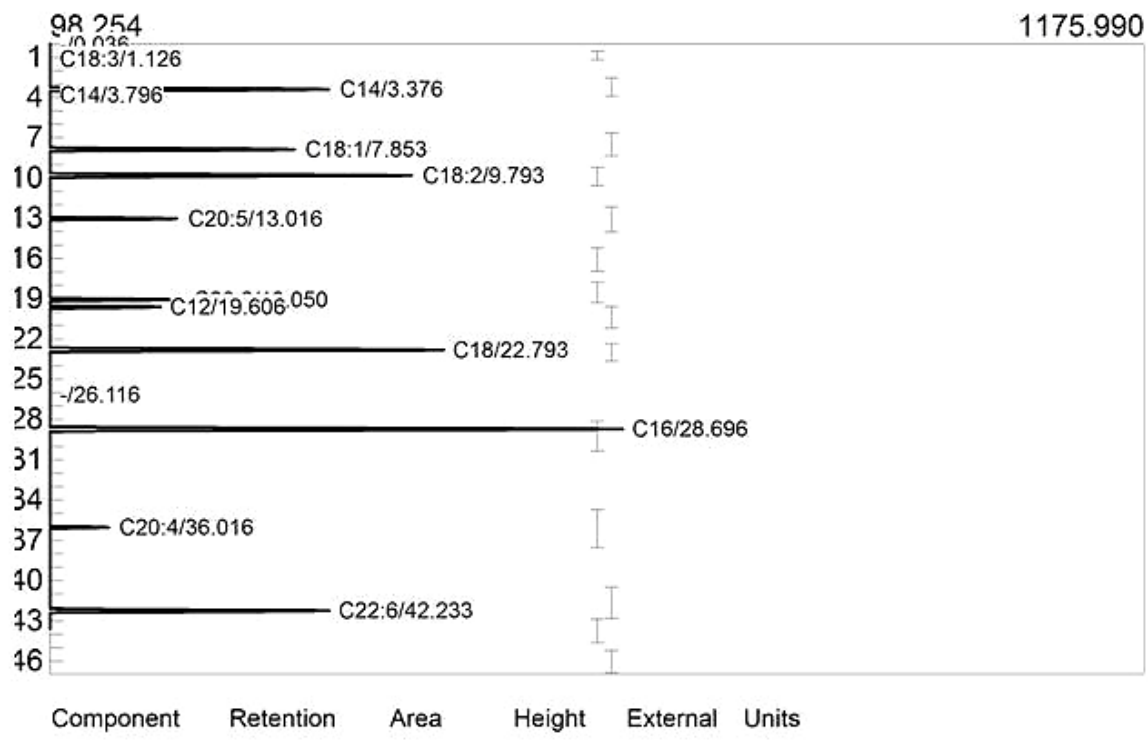

Figure 2. GC-FID spectrum of the bio oil 


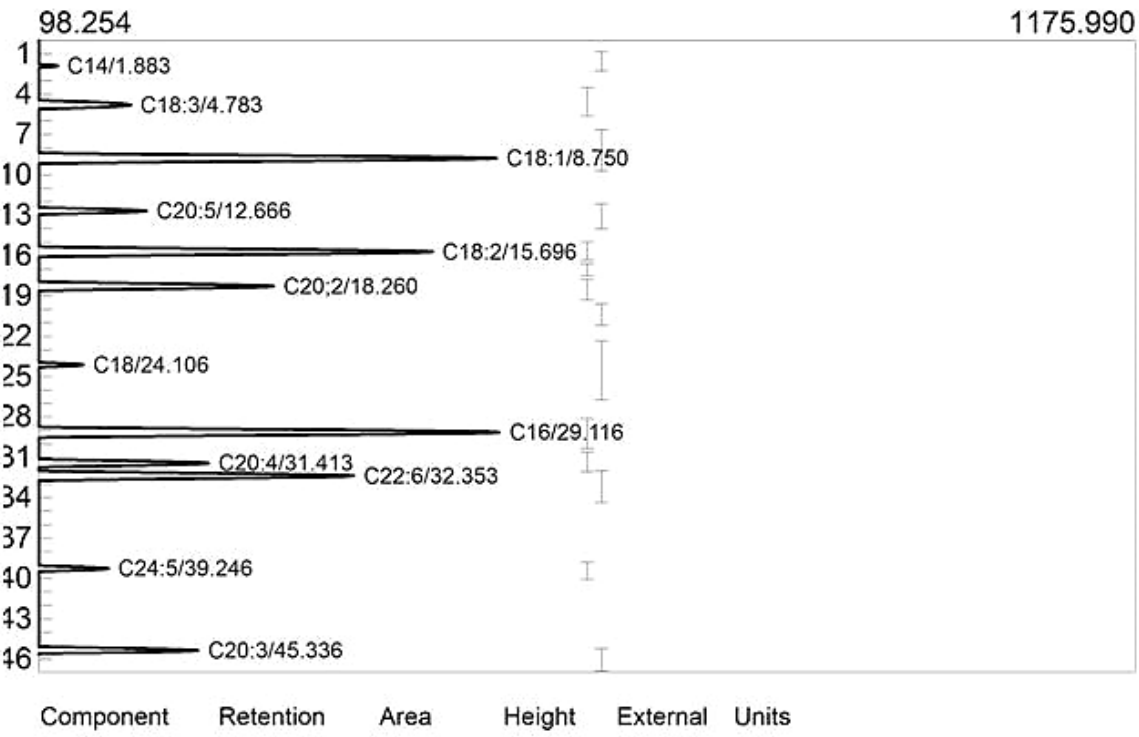

Figure 3. GC-FID spectrum of the produced biodiesel

Table 1. Summary of the fatty acid profile of the bio-oil

\begin{tabular}{clcc}
\hline Component & \multicolumn{1}{c}{ Name } & RT (min) & \% composition \\
\hline C18:3 & Linolenic acid & 1.126 & 0.178532 \\
C14 & Myristic acid & 3.376 & 0.801708 \\
C18:1 & Oleic acid & 7.853 & 7.652005 \\
C18:2 & Linoleic acid & 9.793 & 14.30198 \\
C20:5 & Eicosapentanoic acid & 13.016 & 3.657381 \\
C20:2 & Gondoic acid & 18.936 & 7.628529 \\
C12 & Lauric acid & 19.606 & 2.653383 \\
C18 & Stearic acid & 22.793 & 17.0026 \\
C16 & Palmitic acid & 28.696 & 36.19833 \\
C20:4 & Arachidonic acid & 36.016 & 3.511181 \\
C22:6 & Osbond & 42.233 & 6.294317 \\
\hline
\end{tabular}

Table 2. Summary of the fatty acid profile of the produced biodiesel

\begin{tabular}{clcc}
\hline Component & \multicolumn{1}{c}{ Name } & RT (min) & \% composition \\
\hline C14 & Lauric acid & 1.883 & 3.140543 \\
C18:3 & Linolenic acid & 4.783 & 8.469609 \\
C18:1 & Oleic acid & 8.750 & 13.45768 \\
C20:5 & Eicosapentanoic acid & 12.666 & 3.554962 \\
C18:2 & Linoleic acid & 15.696 & 16.61874 \\
C20:2 & Gondoic acid & 18.260 & 11.96552 \\
C18 & Stearic acid & 24.106 & 5.490978 \\
C16 & Palmitic acid & 29.116 & 19.7915 \\
C20:4 & Arachidonic acid & 31.413 & 6.18783 \\
C22:6 & Osbond & 32.353 & 7.303004 \\
C24:5 & Nervonic acid & 39.246 & 1.500221 \\
C20:3 & Dihomolinolenic acid & 45.336 & 2.506957 \\
\hline
\end{tabular}

From the fatty acid profile of the oil obtained from the raffia palm fruit shown in Table 1, the percentage composition of the saturated fatty acids $(\mathrm{C} 4: 0-\mathrm{C} 24: 0)$ is $56.66 \%$, the prominent saturated fatty acids being palmitic acid $(36.198 \%)$ and stearic acid $(17.003 \%)$. The percentage composition of the unsaturated fatty acids is $43.34 \%$ and the prominent unsaturated fatty acid is linoleic acid $(14.302 \%)$. The ratio of the bio-oil polyunsaturated to saturated 
$(\mathrm{P} / \mathrm{S})$ is 0.79 which shows that the oil is unsuitable for human consumption. It had been reported that the higher the $\mathrm{P} / \mathrm{S}$ value of an oil, the better it is for human consumption [49-51]. From this analysis, the bio-oil seems not to be a good feedstock for biodiesel production because of its high content of saturated fatty acids. Vegetable or seed oils with high composition of saturated fatty acids such as palmitic and stearic acids produces biodiesel having low cold flow properties [52]. As noted by Bello et al. [53], biodiesel with low cold flow properties results in the formation of gum and crystallization of fuel particles at high temperatures resulting in damages to engine parts such as pumps and injectors as well as clogging of fuel lines and fuel filters. However, the results of the produced biodiesel fatty acid profile presented in Figure 3 and summarized in Table 2 gives the percentage of saturated fatty acid as $28.343 \%$, the prominent ones being aplitic acid $(19.792 \%)$ and stearic acid $(5.491 \%)$ while the percentage of the unsaturated fatty acids was $71.657 \%$, the prominent ones being linoleic acid (16.619\%) and oleic acid (13.458\%). Studies had shown that biodiesel with these unsaturated fatty acids possess good cold flow performance as a result of better pour and cloud point of the fuel. This is as a result of the presence of double bonds in the linoleic and oleic acids that forms a cis-cis configuration which eventually reduces the intermolecular attraction that lowers the melting point of the fuel [52. 54]. The production of biodiesel with low saturated fatty acid component from bio-oil with high saturated fatty acid components may be as a result of the novel heterogeneous catalyst produced from turtle shell and its configuration. The contribution of the combination of the process variables may also be responsible for the results obtained. Comparison of the fuel properties of the produced biodiesel with that of petroleum diesel, shows that the biodiesel exhibit better fuel characteristics as can be seen in Table 3 below

Table 3. Fuel properties of the biodiesel and petroleum diesel

\begin{tabular}{lccc}
\hline \multicolumn{1}{c}{ Physicochemical property } & Produced biodiesel & Petroleum diesel & Test method \\
\hline Density $\left(\mathrm{g} / \mathrm{cm}^{3}\right)$ & 0.91 & 0.835 & ASTM D9448-1972 \\
Kinematic viscosity $@ 40^{\circ} \mathrm{C}(\mathrm{cst})$ & 6.43 & 2.83 & ASTM D445 \\
Flash point $\left({ }^{\circ} \mathrm{C}\right)$ & 186 & 70 & ASTM D7215 \\
Pour point $\left({ }^{\circ} \mathrm{C}\right)$ & -2 & 3 & ASTM D2500 \\
Cloud point $\left({ }^{\circ} \mathrm{C}\right)$ & 0.00 & 6.4 & ASTM D97 \\
Cetane number $(\mathrm{N})$ & 69 & 48 & ASTM D6890 \\
\hline
\end{tabular}

\subsection{Effect of Process Variables on Product Yield}

\subsubsection{Effect of $\mathrm{KOH}$ Concentration on Biodiesel Yield}

Figure 4 shows the effect of the concentration of $\mathrm{KOH}$ used as impregnator for the catalyst on the yield of biodiesel. The objective of the impregnation was to increase the catalyst basic strength. As can be seen from Figure 4, increasing the concentration of $\mathrm{KOH}$ in the impregnation process increased the biodiesel yield due to the increased basicity of the catalyst and increased active sites. A maximum biodiesel yield of $93 \%$ was recorded at an optimum $\mathrm{KOH}$ concentration of $30 \%(\mathrm{w} / \mathrm{w})$. Further increase of $\mathrm{KOH}$ concentration above the optimum appeared not to favour biodiesel yield. The reduced biodiesel yield at higher $\mathrm{KOH}$ concentrations may be due to the exhaustion of the active sites on the catalyst surface as reported by Singh et al. [43] and Hadiyanto et al. [32].

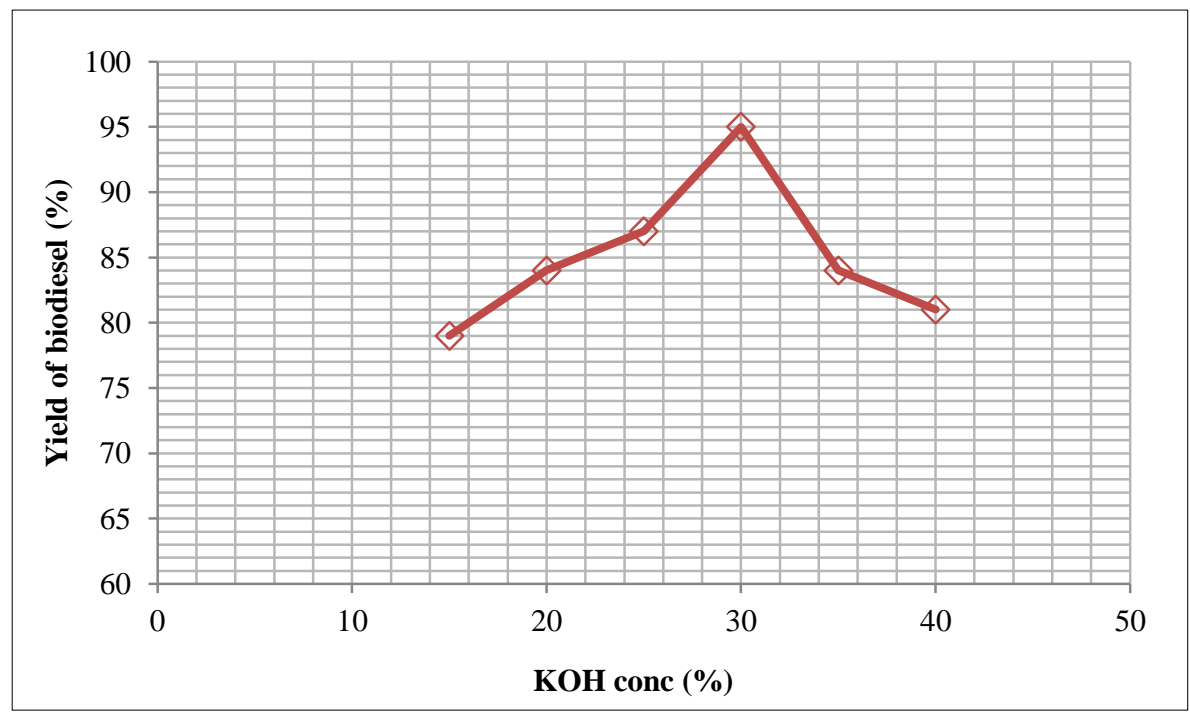

Figure 4. Effect of KOH concentration on biodiesel yield 


\subsubsection{Effect of Catalyst Loading on Biodiesel Yield}

Figure 5 shows the effect of catalyst loading on the yield of biodiesel using $30 \%(\mathrm{w} / \mathrm{w})$ of $\mathrm{KOH}$ concentration. Biodiesel yield increases to a maximum of $92 \%$ as catalyst loading increases up to $6.5 \mathrm{wt} \%$. This marginal linear increase may be due to increased catalytic driving force as reported by Akhihiero et al., [23], however, as the catalyst loading increases beyond $6.5 \%$, biodiesel yield began to decline. The decline in biodiesel yield at higher catalyst loadings may be as a result of increased in viscosity caused by catalyst overload which limits the reaction rate. This is in agreement with the results of both Chen et al. [24] and Ali et al. [41].

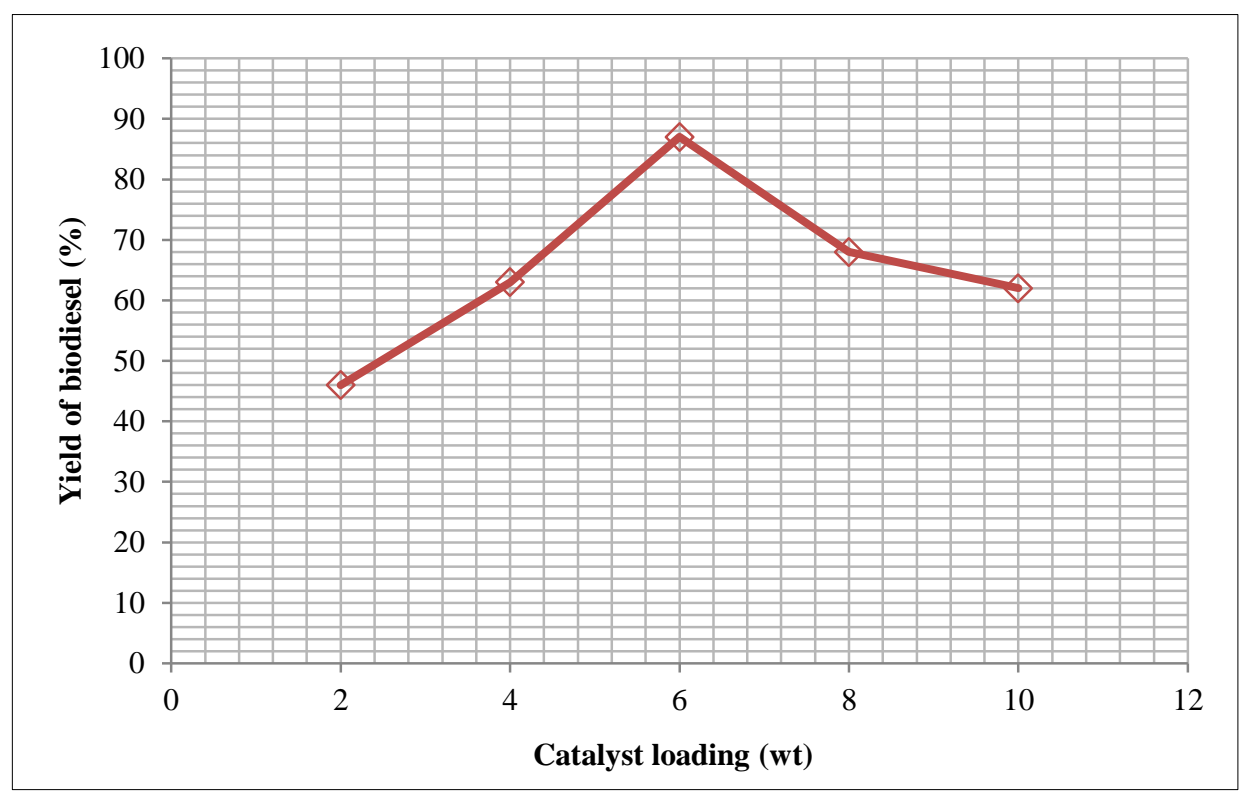

Figure 5. Effect of catalyst loading on biodiesel yield

\subsubsection{Effect of Acetone Co-solvent/methanol Ratio on Biodiesel Yield}

Using $\mathrm{KOH}$ concentration of $30 \%(\mathrm{w} / \mathrm{w})$ and catalyst loading of $6.5 \%(\mathrm{w} / \mathrm{w})$, the influence of acetone cosolvent/methanol ratio on biodiesel yield was studied and the result is presented in Figure 6. The primary aim of adding a co-solvent in a transesterification process is to improve miscibility of the reacting species so as to reduce reaction time. The reaction time was reduced from $5 \mathrm{hr}$ to $0.5 \mathrm{hr}$ in order to ascertain the impact of the co-solvent on the reaction rate. As can be seen from the figure, biodiesel yield increases as acetone/methanol ratio increases up to 0.4 at a maximum yield of $65 \%$. Further increase in acetone/methanol ratio showed marginal decline in biodiesel yield and this may be due to over-dilution of the methanol by acetone. Similar result was obtained by Elkady et al. [29].

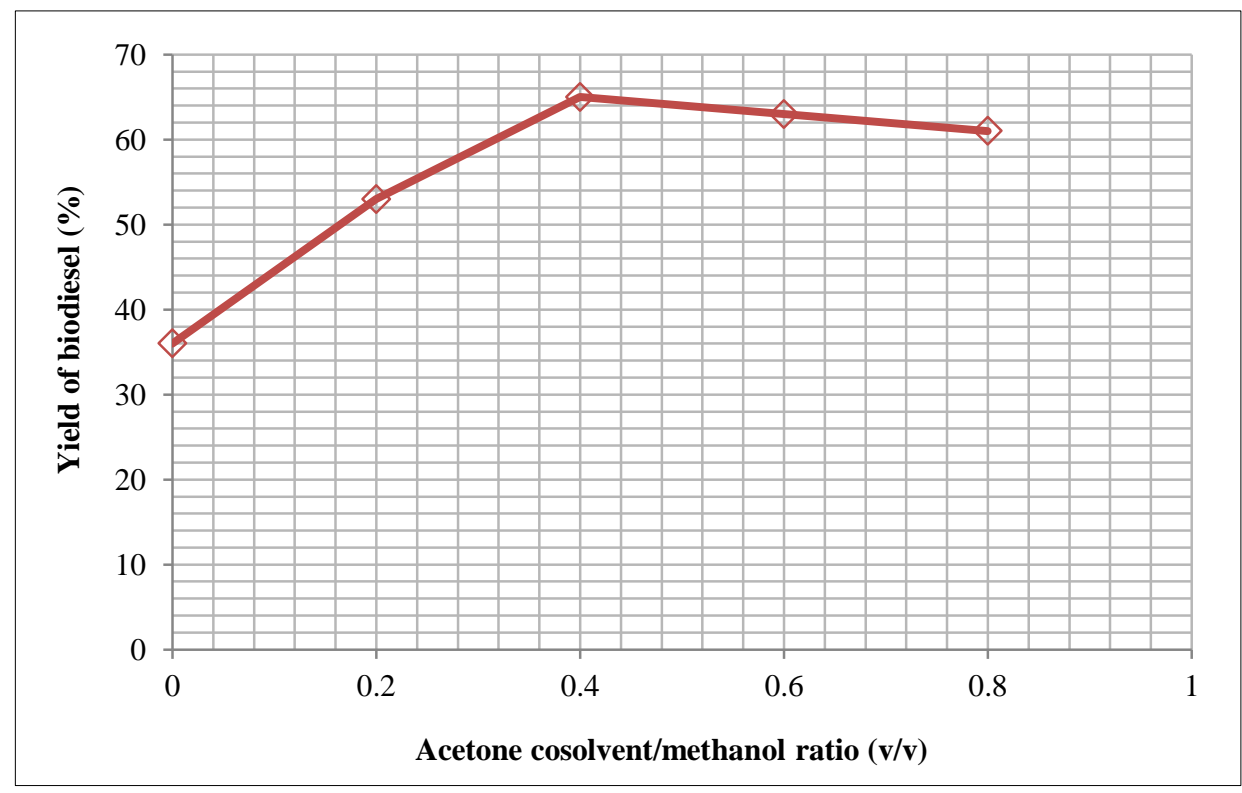

Figure 6. Effect of acetone co-solvent/methanol ratio (v/v) on biodiesel yield 


\subsubsection{Effect of Catalyst/Carbon Ratio on Biodiesel Yield}

Using $\mathrm{KOH}$ concentration of $30 \%(\mathrm{w} / \mathrm{w})$, catalyst loading of $6.5 \%$ and acetone co-solvent/methanol ratio of 0.4 , the effect of catalyst/carbon ratio on biodiesel yield was studied and the result is presented in Figure 7 . The catalytic property of a heterogeneous catalyst is highly dependent on its surface area which can be increased by supporting the catalyst with activated carbon [55]. However, an appropriate mix ratio is needed to obtain the desired catalytic activity. As can be seen from the figure, at a low catalyst/carbon weight ratio, biodiesel yield was low because of the availability of less active components. Increasing the ratio was seen to greatly improve biodiesel yield, and the maximum yield of $93 \%$ was obtained at a ratio of 1.25 . Further increase of catalyst/carbon ratio led to a slight decline in biodiesel yield as a result of reduced surface area. Signh et al. [43] and Hadiyanto et al. [32] reported similar results in their work.

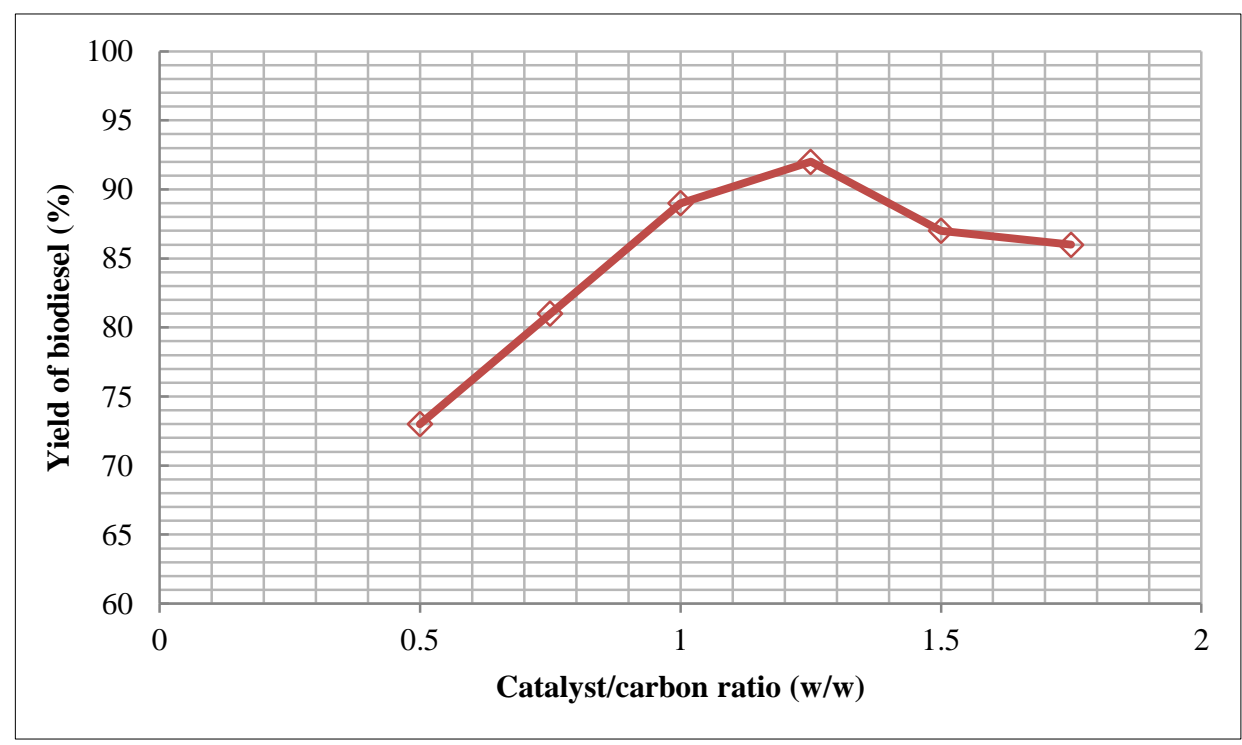

Figure 7. Effect of catalyst/carbon ratio (w/w) on biodiesel yield

\section{Conclusion}

The possibility of producing biodiesel from a non-convectional source, raphia africana oil, using a heterogeneous catalyst derived from turtle shells supported with activated carbon produced from cassava peels, has been carried out. The present study, which is novel in nature, shows that bio-oil with a high content of saturated fatty acids can be used to produce biodiesel with high fuel quality and a low saturated fatty acid profile. The application of acetone as a cosolvent in the transesterification reaction is another factor that improves the yield of the resultant biodiesel. Turtle shells and raphia palms that are prevalent in the riverine areas of Nigeria's Niger Delta are, therefore, ready feedstock for biodiesel production.

\section{Declarations}

\subsection{Author Contributions}

Conceptualization, H.E.O. and K.M.O. methodology, H.E.O., K.M.O. and U.M.O.; software, U.M.O.; validation, H.E.O., K.M.O. and O.E.O.; formal analysis, U.M.O.; investigation, K.M.O. and H.E.O.; resources, K.M.O., and O.E.O.; data curation, K.M.O., H.O.O. and U.M.O.; writing-original draft preparation, H.O.O., and U.M.O.; writing - review and editing, K.M.O., and O.E.O.; visualization, K.M.O.; supervision, K.M.O.; project administration, K.M.O.; funding acquisition, K.M.O, and O.E.O. All authors have read and agreed to the published version of the manuscript.

\subsection{Data Availability Statement}

The data presented in this study are available in article.

\subsection{Funding}

The authors received no financial support for the research, authorship, and/or publication of this article.

\subsection{Acknowledgements}

The authors thank Mr.Adedeji Adebayo and Mrs Judith Umukoro; Laboratory Technologists at the Chemical Engineering Departments of the Federal University of Petroleum Resources Effurun-Warri and Delta State University Oleh Campus respectively for their skilled technical assistance during the experimental stage of this study. 


\subsection{Institutional Review Board Statement}

Not applicable.

\subsection{Informed Consent Statement}

Not applicable.

\subsection{Declaration of Competing Interest}

The authors declare that there is no conflict of interests regarding the publication of this manuscript. In addition, the ethical issues, including plagiarism, informed consent, misconduct, data fabrication and/or falsification, double publication and/or submission, and redundancies have been completely observed by the authors.

\section{References}

[1] Alamu, O. J., Waheed, M. A., \& Jekayinfa, S. O. (2007). Biodiesel production from Nigerian palm kernel oil: effect of KOH concentration on yield. Energy for Sustainable Development, 11(3), 77-82. doi:10.1016/S0973-0826(08)60579-7.

[2] Boz, N., Degirmenbasi, N., \& Kalyon, D. M. (2013). Transesterification of canola oil to biodiesel using calcium bentonite functionalized with K compounds. Applied Catalysis B: Environmental, 138-139, 236-242. doi:10.1016/j.apcatb.2013.02.043.

[3] Wong, W. Y., Lim, S., Pang, Y. L., Shuit, S. H., Chen, W. H., \& Lee, K. T. (2020). Synthesis of renewable heterogeneous acid catalyst from oil palm empty fruit bunch for glycerol-free biodiesel production. Science of the Total Environment, 727. doi:10.1016/j.scitotenv.2020.138534.

[4] Orugba, H. O., Ogbeide, S. E., \& Osagie, C. (2019). Emission Trading Scheme and the Effect of Carbon Fee on Petroleum Refineries. Asian Journal of Applied Sciences, 7(5), 537-545. doi:10.24203/ajas.v7i5.5947.

[5] Ahmadi, M. H., Ghazvini, M., Alhuyi Nazari, M., Ahmadi, M. A., Pourfayaz, F., Lorenzini, G., \& Ming, T. (2018). Renewable energy harvesting with the application of nanotechnology: A review. International Journal of Energy Research, 43(4), 13871410. doi:10.1002/er.4282.

[6] Bouraiou, A., Necaibia, A., Boutasseta, N., Mekhilef, S., Dabou, R., Ziane, A., Sahouane, N., Attoui, I., Mostefaoui, M., \& Touaba, O. (2020). Status of renewable energy potential and utilization in Algeria. Journal of Cleaner Production, $246,119011$. doi:10.1016/j.jclepro.2019.119011.

[7] Singh, R., Bux, F., \& Sharma, Y. C. (2020). Optimization of biodiesel synthesis from microalgal (Spirulina platensis) oil by using a novel heterogeneous catalyst, $\beta$-strontium silicate ( $\beta$-Sr2SiO4). In Fuel (Vol. 280). doi:10.1016/j.fuel.2020.118312.

[8] Faruque, M. O., Razzak, S. A., \& Hossain, M. M. (2020). Application of heterogeneous catalysts for biodiesel production from microalgal oil—a review. Catalysts, 10(9), 1-25. doi:10.3390/catal10091025.

[9] Panwar, N. L., Kaushik, S. C., \& Kothari, S. (2011). Role of renewable energy sources in environmental protection: A review. Renewable and Sustainable Energy Reviews, 15(3), 1513-1524. doi:10.1016/j.rser.2010.11.037.

[10] Can, I. (2012). Experimental investigation effects of blend hazelnut oil on compression ignition engine performance characteristics and emission. Journal of Renewable and Sustainable Energy, 4(4), 42701. doi:10.1063/1.4737921.

[11] Barua, P., Dutta, K., Basumatary, S., \& Deka, D. C. (2014). Seed oils from non-conventional sources in north-east India: Potential feedstock for production of biodiesel. Natural Product Research, 28(8), 577-580. doi:10.1080/14786419.2014.881361.

[12] Abdullah, S. H. Y. S., Hanapi, N. H. M., Azid, A., Umar, R., Juahir, H., Khatoon, H., \& Endut, A. (2017). A review of biomass-derived heterogeneous catalyst for a sustainable biodiesel production. Renewable and Sustainable Energy Reviews, 70, 1040-1051. doi:10.1016/j.rser.2016.12.008.

[13] Asri, N. P., Machmudah, S., Wahyudiono, Suprapto, Budikarjono, K., Roesyadi, A., \& Goto, M. (2013). Palm oil transesterification in sub- and supercritical methanol with heterogeneous base catalyst. Chemical Engineering and Processing: Process Intensification, 72, 63-67. doi:10.1016/j.cep.2013.07.003.

[14] Mat Yasin, M. H., Yusaf, T., Mamat, R., \& Fitri Yusop, A. (2014). Characterization of a diesel engine operating with a small proportion of methanol as a fuel additive in biodiesel blend. Applied Energy, 114, 865-873. doi:10.1016/j.apenergy.2013.06.012.

[15] Oghenejoboh, K. M., \& Umukoro, P. O. (2011). Comparative analysis of fuel characteristics of bio-diesel produced from selected oil-bearing seeds in Nigeria. European Journal of Scientific Research, 58(2), 238-246.

[16] Subramaniam, D., Murugesan, A., \& Avinash, A. (2013). Performance and emission evaluation of biodiesel fueled diesel engine abetted with exhaust gas recirculation and Ni coated catalytic converter. Journal of Renewable and Sustainable Energy, 5(2), 23138. doi:10.1063/1.4802943. 
[17] Gumahin, A. C., Galamiton, J. M., Allerite, M. J., Valmorida, R. S., Laranang, J. R. L., Mabayo, V. I. F., Arazo, R. O., \& Ido, A. L. (2019). Response surface optimization of biodiesel yield from pre-treated waste oil of rendered pork from a food processing industry. Bioresources and Bioprocessing, 6(1). doi:10.1186/s40643-019-0284-2.

[18] Mansir, N., Teo, S. H., Rashid, U., Saiman, M. I., Tan, Y. P., Alsultan, G. A., \& Taufiq-Yap, Y. H. (2018). Modified waste egg shell derived bifunctional catalyst for biodiesel production from high FFA waste cooking oil. A review. Renewable and Sustainable Energy Reviews, 82, 3645-3655. doi:10.1016/j.rser.2017.10.098.

[19] Mat Yasin, M. H., Yusaf, T., Mamat, R., \& Fitri Yusop, A. (2014). Characterization of a diesel engine operating with a small proportion of methanol as a fuel additive in biodiesel blend. Applied Energy, 114, 865-873. doi:10.1016/j.apenergy.2013.06.012.

[20] Xue, J., Grift, T. E., \& Hansen, A. C. (2011). Effect of biodiesel on engine performances and emissions. Renewable and Sustainable Energy Reviews, 15(2), 1098-1116. doi:10.1016/j.rser.2010.11.016.

[21] Rajagopal, K., Bindu, C., Prasad, R. B. N., \& Ahmad, A. (2016). The effect of fatty acid profiles of biodiesel on key fuel properties of some biodiesels and blends. Energy Sources, Part A: Recovery, Utilization and Environmental Effects, 38(11), 1582-1590. doi:10.1080/15567036.2014.929758.

[22] Selaimia, R., Beghiel, A., \& Oumeddour, R. (2015). The Synthesis of Biodiesel from Vegetable Oil. Procedia - Social and Behavioral Sciences, 195, 1633-1638. doi:10.1016/j.sbspro.2015.06.221.

[23] Akhihiero, E. T., Oghenejoboh, K. M., \& Umukoro, P. O. (2013). Effects of Process Variables on Transesterification Reaction of Jatropha Curcas Seed Oil for the Production of Biodiesel. International Journal of Emerging Technology and Advanced Engineering, 3(6), 388-393.

[24] Chen, Y. H., Huang, Y. H., Lin, R. H., \& Shang, N. C. (2010). A continuous-flow biodiesel production process using a rotating packed bed. Bioresource Technology, 101(2), 668-673. doi:10.1016/j.biortech.2009.08.081.

[25] Jayathilakan, K., Sultana, K., Radhakrishna, K., \& Bawa, A. S. (2012). Utilization of byproducts and waste materials from meat, poultry and fish processing industries: A review. Journal of Food Science and Technology, 49(3), 278-293. doi:10.1007/s13197-011-0290-7.

[26] Baladincz, P., \& Hancsók, J. (2015). Fuel from waste animal fats. Chemical Engineering Journal, 282, 152-160. doi:10.1016/j.cej.2015.04.003.

[27] Elkady, M. F., Zaatout, A., \& Balbaa, O. (2015). Production of Biodiesel from Waste Vegetable Oil via KM Micromixer. Journal of Chemistry, 2015. doi:10.1155/2015/630168.

[28] Prueksakorn, K., \& Gheewala, S. H. (2008). Full chain energy analysis of biodiesel from jatropha curcas L in Thailand. Environmental Science and Technology, 42(9), 3388-3393. doi:10.1021/es7022237.

[29] Ito, T., Nakashimada, Y., Senba, K., Matsui, T., \& Nishio, N. (2005). Hydrogen and ethanol production from glycerolcontaining wastes discharged after biodiesel manufacturing process. Journal of Bioscience and Bioengineering, 100(3), 260265. doi:10.1263/jbb.100.260.

[30] Ejikeme, P. M., Anyaogu, I. D., Ejikeme, C. L., Nwafor, N. P., Egbuonu, C. A. C., Ukogu, K., \& Ibemesi, J. A. (2010). Catalysis in biodiesel production by transesterification processes-an insight. E-Journal of Chemistry, 7(4), 1120-1132. doi:10.1155/2010/689051.

[31] Nurfitri, I., Maniam, G. P., Hindryawati, N., Yusoff, M. M., \& Ganesan, S. (2013). Potential of feedstock and catalysts from waste in biodiesel preparation: A review. Energy Conversion and Management, 74, 395-402. doi:10.1016/j.enconman.2013.04.042.

[32] Hadiyanto, H., Afianti, A. H., Navi'A, U. I., Adetya, N. P., Widayat, W., \& Sutanto, H. (2017). The development of heterogeneous catalyst $\mathrm{C} / \mathrm{CaO} / \mathrm{NaOH}$ from waste of green mussel shell (Perna varidis) for biodiesel synthesis. Journal of Environmental Chemical Engineering, 5(5), 4559-4563. doi:10.1016/j.jece.2017.08.049.

[33] Guldhe, A., Moura, C. V. R., Singh, P., Rawat, I., Moura, E. M., Sharma, Y., \& Bux, F. (2017). Conversion of microalgal lipids to biodiesel using chromium-aluminum mixed oxide as a heterogeneous solid acid catalyst. Renewable Energy, 105, 175-182. doi:10.1016/j.renene.2016.12.053.

[34] Leung, D. Y. C., Wu, X., \& Leung, M. K. H. (2010). A review on biodiesel production using catalyzed transesterification. Applied Energy, 87(4), 1083-1095. doi:10.1016/j.apenergy.2009.10.006.

[35] Hu, S., Wang, Y., \& Han, H. (2011). Utilization of waste freshwater mussel shell as an economic catalyst for biodiesel production. Biomass and Bioenergy, 35(8), 3627-3635. doi:10.1016/j.biombioe.2011.05.009.

[36] Birla, A., Singh, B., Upadhyay, S. N., \& Sharma, Y. C. (2012). Kinetics studies of synthesis of biodiesel from waste frying oil using a heterogeneous catalyst derived from snail shell. Bioresource Technology, 106, 95-100. doi:10.1016/j.biortech.2011.11.065. 
[37] Obadiah, A., Swaroopa, G. A., Kumar, S. V., Jeganathan, K. R., \& Ramasubbu, A. (2012). Biodiesel production from Palm oil using calcined waste animal bone as catalyst. Bioresource Technology, 116, 512-516. doi:10.1016/j.biortech.2012.03.112.

[38] De Sousa, F. P., Dos Reis, G. P., Cardoso, C. C., Mussel, W. N., \& Pasa, V. M. D. (2016). Performance of CaO from different sources as a catalyst precursor in soybean oil transesterification: Kinetics and leaching evaluation. Journal of Environmental Chemical Engineering, 4(2), 1970-1977. doi:10.1016/j.jece.2016.03.009.

[39] Putra, M. D., Irawan, C., Udiantoro, Ristianingsih, Y., \& Nata, I. F. (2018). A cleaner process for biodiesel production from waste cooking oil using waste materials as a heterogeneous catalyst and its kinetic study. Journal of Cleaner Production, 195, 1249-1258. doi:10.1016/j.jclepro.2018.06.010.

[40] Sulaiman, S., \& Amin, M. H. M. (2016). Fish bone-catalyzed methanolysis of waste cooking oil. Bulletin of Chemical Reaction Engineering \& Catalysis, 11(2), 245-249. doi:10.9767/bcrec.11.2.556.245-249.

[41] Ali, C. H., Asif, A. H., Iqbal, T., Qureshi, A. S., Kazmi, M. A., Yasin, S., Danish, M., \& Mu, B. Z. (2018). Improved transesterification of waste cooking oil into biodiesel using calcined goat bone as a catalyst. Energy Sources, Part A: Recovery, Utilization and Environmental Effects, 40(9), 1076-1083. doi:10.1080/15567036.2018.1469691.

[42] Buasri, A., Worawanitchaphong, P., Trongyong, S., \& Loryuenyong, V. (2014). Utilization of Scallop Waste Shell for Biodiesel Production from Palm Oil - Optimization Using Taguchi Method. APCBEE Procedia, 8, $216-221$. doi:10.1016/j.apcbee.2014.03.030.

[43] Singh, A. P., He, B. B., Thompson, J. C., \& Van Gerpen, J. H. (2006). Process optimization of biodiesel production using alkaline catalysts. Applied Engineering in Agriculture, 22(4), 597-600. doi:10.13031/2013.21213.

[44] Zhang, J., \& Meng, Q. (2014). Preparation of KOH/CaO/C Supported Biodiesel Catalyst and Application Process. World Journal of Engineering and Technology, 02(03), 184-191. doi:10.4236/wjet.2014.23020.

[45] Wembabazi, E., Mugisha, P. J., Ratibu, A., Wendiro, D., Kyambadde, J., \& Vuzi, P. C. (2015). Spectroscopic analysis of heterogeneous biocatalysts for biodiesel production from expired sunflower cooking oil. Journal of Spectroscopy, $2015,1-8$. doi:10.1155/2015/714396.

[46] Qi, G. J. (2011). Si-N-C Nanowires Derived by Polyhydridomethylsilazane Pyrolysis. Materials Sciences and Applications, 02(07), 936-939. doi:10.4236/msa.2011.27124.

[47] Alhassan, Y., Kumar, N., Bugaje, I. M., Pali, H. S., \& Kathkar, P. (2014). Co-solvents transesterification of cotton seed oil into biodiesel: Effects of reaction conditions on quality of fatty acids methyl esters. Energy Conversion and Management, 84, 640648. doi:10.1016/j.enconman.2014.04.080.

[48] Xie, J., Zheng, X., Dong, A., Xiao, Z., \& Zhang, J. (2009). Biont shell catalyst for biodiesel production. Green Chemistry, 11(3), 355-36. doi:10.1039/b812139g.

[49] Kostik, V., Memeti, S., \& Bauer, B. (2013). Fatty acid composition of edible oils and fats. Journal of Hygienic Engineering and Design, 4, 112-116.

[50] Bialek, A., Bialek, M., Jelinska, M., \& Tokarz, A. (2017). La composición de ácidos grasos y las características de aceites comestibles innovadores en Polonia. CYTA - Journal of Food, 15(1), 1-8. doi:10.1080/19476337.2016.1190406.

[51] Orsavova, J., Misurcova, L., Vavra Ambrozova, J., Vicha, R., \& Mlcek, J. (2015). Fatty acids composition of vegetable oils and its contribution to dietary energy intake and dependence of cardiovascular mortality on dietary intake of fatty acids. International Journal of Molecular Sciences, 16(6), 12871-12890. doi:10.3390/ijms160612871.

[52] Folayan, A. J., Anawe, P. A. L., Aladejare, A. E., \& Ayeni, A. O. (2019). Experimental investigation of the effect of fatty acids configuration, chain length, branching and degree of unsaturation on biodiesel fuel properties obtained from lauric oils, high-oleic and high-linoleic vegetable oil biomass. Energy Reports, 5, 793-806. doi:10.1016/j.egyr.2019.06.013.

[53] Bello, E. I., Adekanbi, I. T., \& Akinbode, F. O. (2015). Production and Characterization of Coconut (Cocos Nucifera) Oil and Its Methyl Ester. European Journal of Engineering and Technology, 3(3), 25-35. www.idpublications.org

[54] Verma, P., Sharma, M. P., \& Dwivedi, G. (2016). Evaluation and enhancement of cold flow properties of palm oil and its biodiesel. Energy Reports, 2, 8-13. doi:10.1016/j.egyr.2015.12.001.

[55] Iwanow, M., Gärtner, T., Sieber, V., \& König, B. (2020). Activated carbon as catalyst support: Precursors, preparation, modification and characterization. Beilstein Journal of Organic Chemistry, 16, 1188-1202. doi:10.3762/bjoc.16.104. 